See discussions, stats, and author profiles for this publication at: https://www.researchgate.net/publication/236346671

\title{
What is the main food source of the shipworm (Teredo navalis)? A stable isotope approach
}

Article in Journal of Sea Research · March 2013

DOI: 10.1016/j.seares.2013.03.003

2 authors, including:

Peter Paalvast

ecoconsult, the Netherlands

44 PUBLICATIONS 306 CITATIONS

SEE PROFILE

Some of the authors of this publication are also working on these related projects:

Project Ecologische optimalisatie ligplaatsen binnenvaart aan het Calandkanaal. View project

Project MER Haringvlietsluizen View project 


\section{Chapter 4}

What is the main food source of the shipworm (Teredo navalis)? A stable isotope approach

Peter Paalvast

Gerard van der Velde

Journal of Sea Research 80 (2013) 58-60

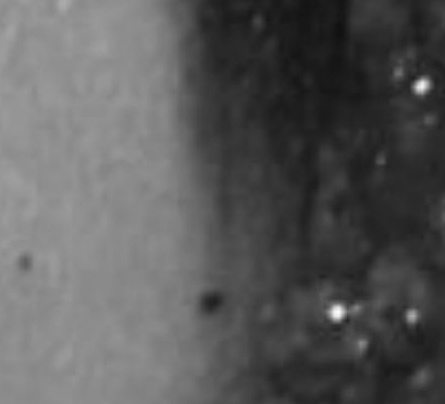




\section{Chapter 4}

\section{Abstract}

Stable isotope analysis of soft bodies of the shipworm Teredo navalis demonstrated that this species is mainly feeding on seston by filter feeding in contrast to wood consumption. Teredo navalis showed similar stable isotope values $\left(\delta^{13} \mathrm{C}, \delta^{15} \mathrm{~N}\right)$ as Mytilus edulis and Crassostrea gigas, which species were attached to the wood instead of boring into. 


\section{Introduction}

Boring behaviour protects bivalves against predation while they filter feed consuming seston. Within boring bivalves belonging to the Pholadacea two families are usually distinguished viz. Pholadidae (Angel Wings) which bore into hardened peat, wood, soft chalkstone, corals (and even ABS pipes e.g. Jenner et al., 2003) and Teredinidae (Shipworms) which are specialized to bore into wood (Turner, 1966). It is an ongoing debate if some species of the Teredinidae are able to feed on wood exclusively, or on symbiotic bacteria feeding on wood or also feed on seston (suspended organic matter: plankton and detritus) as additional or as main food source (e.g. Nair and Saraswathy, 1971, Pechenik et al., 1979 and literature therein).

Within specialized epithelial cells of several members of the Teredinidae, associations of symbiotic cellulolytic nitrogen fixing bacteria were found within the gills (Distel et al., 1991, Distel et al., 2002, Sipe et al., 2000, Betcher et al., 2012). Wood contains a very low level of nitrogen and has so a very high $\mathrm{C} / \mathrm{N}$ ratio (Distel, 2003) and therefore the atmospheric nitrogen usable for some shipworm species fixed by endosymbionts (Lechene et al., 2007) may be the main source.

One of the most common teredinid species is Teredo navalis. Popham and Dickson (1973) demonstrated bacterial associations in the gills of $T$. navalis indicating that this species may be able to feed solely on wood. Mann and Gallager (1985) found no significant growth enhancement in the presence of a phytoplankton supplement (in addition to wood), which could suggest wood as the primary food resource. Paalvast and Van der Velde (2011) suggest that individuals that bore into hardwood need to acquire extra nourishment by filtration for at least their basal metabolism, and that this also accounts in highly infested wood when there is no more wood left to bore into.

To find out what $T$. navalis is mainly consuming can nowadays be tested by stable isotope analysis. Carbon isotope ratios $\left(\delta^{13} \mathrm{C}\right)$ in animal tissues closely resemble the food consumed over longer period of time, meaning you are (almost) what you eat. The enrichment in $\delta^{13} \mathrm{C}$ in the consumer compared with its diet lies within 0 to $1 \%$ (DeNiro and Epstein, 1978, Rau et al., 1983, Fry et al., 1984, Gu et al., 1996, Vander Zanden et al., 1997, Vander Zanden et al., 1999). The nitrogen ratio $\left(\delta^{15} \mathrm{~N}\right)$ increases by $3.4 \pm 1.1 \%$ with each trophic level through the food web (DeNiro and Epstein, 1978, Minagawa and Wada, 1984, Wada et al., 1987). $\delta^{13} \mathrm{C}$ values indicate the carbon sources, while $\delta^{15} \mathrm{~N}$ values indicate trophic position.

We hypothized that, when $T$. navalis feeds mainly on wood as a carbon source the $\delta^{13} \mathrm{C}$ values of the shipworm would resemble the $\delta^{13} \mathrm{C}$ values of the wood in 


\section{Chapter 4}

which they bore into. When $T$. navalis feeds on seston by filter feeding, than the $\delta^{13} \mathrm{C}$ values of the shipworm resemble the $\delta^{13} \mathrm{C}$ values of other bivalve filter feeders at the same location. We further hypothesized in the case of filter feeding on seston the $\delta^{15} \mathrm{~N}$ values of the shipworm are expected to be at least $3.4 \pm 1.1 \%$ higher than the $\delta{ }^{15} \mathrm{~N}$ of wood and should be similar to the $\delta^{15} \mathrm{~N}$ values of other bivalve filter feeders at the same location.

\section{Material and methods}

To test the above hypotheses the carbon and nitrogen stable isotope composition of the body tissue of the bivalves T. navalis (shipworm), Mytilus edulis (Blue mussel) and Crassostrea gigas (Pacific oyster) and the fir wood (Picea abies) where they lived in or on wood, was analysed.

The shipworms, blue mussels and Pacific oysters were all collected from the last metre near the sea floor of 8 metre long fir beam that was attached to a mooring pole from 3 metres above the mean low water level (MLWL) till the bottom of the sea floor $5 \mathrm{~m}$ below MLWL in the polyhaline Scheurhaven of the port of Rotterdam, the Netherlands (51ํ 57' 43.33" N, 4 8' 16.41" E). The fir beam was attached to the mooring pole in April 2009 and removed in April 2012. The last metre of the pole was cut off and transported to the laboratory of the Radboud University Nijmegen. Mussels and oysters that grew on the beam were removed, shipworms were retrieved by cutting and splitting the beam with an axe and samples of the wood were taken for stable isotope analysis.

In the laboratory, bivalves were rinsed first in tap water and then in distilled water. The soft bodies of 6-8 individuals were pooled for each sample and oven dried at $60{ }^{\circ} \mathrm{C}$ for $3-5$ days. Shells of molluscs and pallets in the case of the shipworm were removed and the remaining body tissue dried for $48 \mathrm{~h}$ at $60^{\circ} \mathrm{C}$, after which specimens were ground to a fine powder using a pestle and mortar and liquid nitrogen. Measurements were carried out for each individual using their powder stored in small new glass bottles with a plastic cap until weighing. Carbon and nitrogen stable isotopic compositions were measured with a Carlo Erba NA 1500 elemental analyzer coupled online via a Finnigan Conflo III interface with a ThermoFinnigan DeltaPlus mass spectrometer. Carbon and nitrogen isotope ratios are expressed in the standard delta notation $\left(\delta^{13} \mathrm{C}, \delta^{15} \mathrm{~N}\right)$ relative to Vienna PDB and atmospheric nitrogen. Average reproducibility based on replicate measurements of internal standards Sucrose (IAEA-CH-6) for $\delta^{13} \mathrm{C}$ and Ammonium sulphate (IAEA-N-2) for $\delta^{15} \mathrm{~N}$ was ca. $0.15 \%$. Acetanilide was used as the laboratory reference. 
Statistical analysis was carried out with SPSS 15.0 for Windows. Anova together with the Levene's test for equality of variance was conducted to compare the means of $\delta^{13} \mathrm{C}$ and $\delta^{15} \mathrm{~N}$ of the species involved.

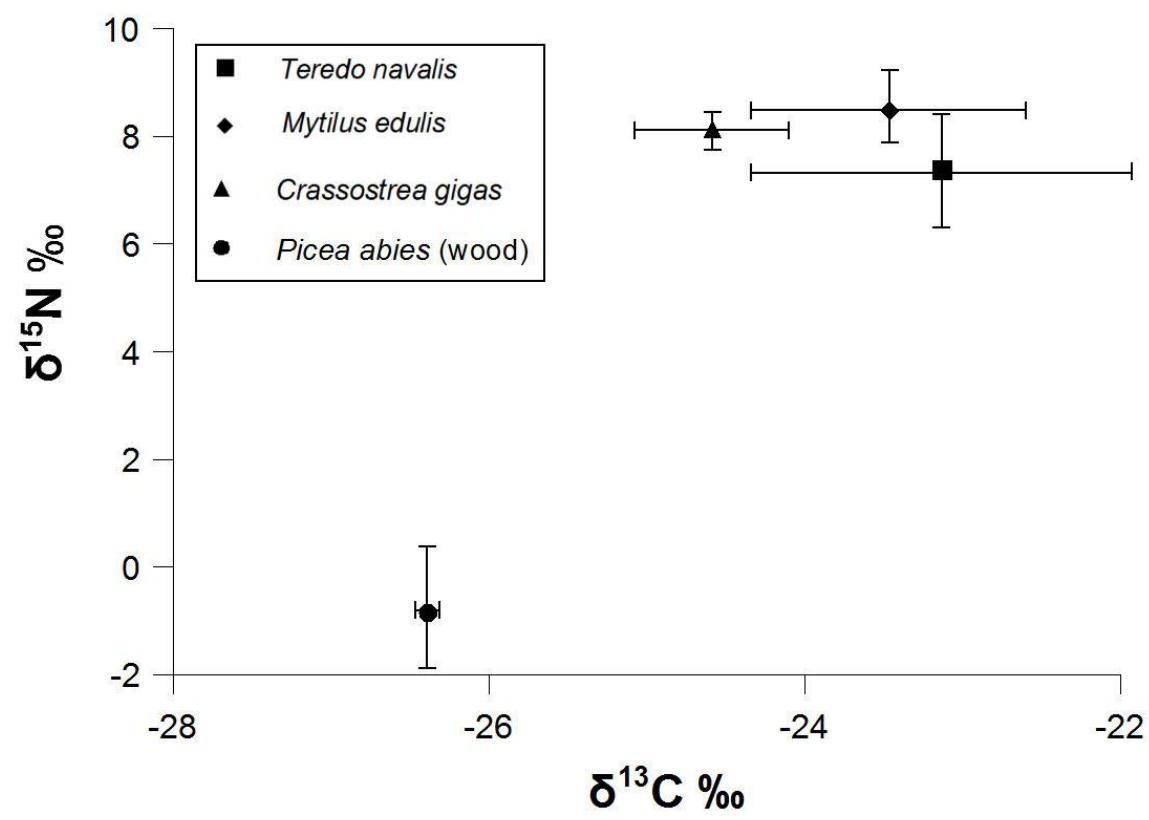

Figure 1 Stable isotope values for the shipworm (Teredo navalis), Blue mussel (Mytilus edulis), Pacific oyster (Crassostrea gigas) and wood (Picea abies).

\section{Results}

As fir wood contains very little nitrogen this led to overflow of 5 of the 9 samples during the stable isotope analyses for this element, but this was not the case for carbon. All other samples did not show any overflow.

There was a significant difference in the means of $\delta^{13} \mathrm{C}$ values between the species (one-way ANOVA, $F(3,52)=31.1, p<0.001$ ) (Fig. 1). Wood $(N=9, M$ $\left(\delta^{13} \mathrm{C}\right)=-26.41 \%$, SE $\left.=0.023\right)$ compared with the bivalves had a significant (Tamhane at the 0.05 level) lower $\delta^{13} \mathrm{C}$ value ranging from $-1.8 \%$ for the Pacific oyster $\left(\mathrm{N}=8, \mathrm{M}\left(\delta^{13} \mathrm{C}\right)=-24.58 \%\right.$, SE $\left.=0.213\right),-3.0 \%$ for the Blue mussel $(\mathrm{N}=$ 23, $M\left(\delta^{13} \mathrm{C}\right)=-23.46 \%$, SE $\left.=0.181\right)$ to $-3.3 \%$ for the shipworm $(\mathrm{N}=16, \mathrm{M}$ $\left(\delta^{13} \mathrm{C}\right)=-23.13 \%$, SE $\left.=0.302\right)$. Furthermore the Pacific oyster's $\delta^{13} \mathrm{C}$ was significantly lower (Tamhane at the 0.05 level) than those of shipworm and Blue mussel. 
There was also a significant difference in the means of $\delta^{15} \mathrm{~N}$ values between the species (one-way ANOVA, $F(3,47)=170.6, p<0.001$ ) (Fig. 1). Wood $(N=4, M$ $\left(\delta^{15} \mathrm{~N}\right)=-0.86 \%$, SE $\left.=0.538\right)$ compared with the bivalves had a significant (Tamhane at the 0.05 level) lower $\delta^{15} \mathrm{~N}$ value ranging from $-8.2 \%$ for the shipworm $\left(N=16, M\left(\delta^{15} N\right)=7.38 \%\right.$, SE $\left.=0.251\right),-9.0 \%$ for the Pacific oyster $\left(\mathrm{N}=8, \mathrm{M}\left(\delta^{15} \mathrm{~N}\right)=8.14, \mathrm{SE}=0.120\right)$ to $-9.3 \%$ for the Blue mussel $(\mathrm{N}=23$, $\mathrm{M}\left(\delta^{15} \mathrm{~N}\right)=8.48 \%$, SE $\left.=0.130\right)$. Between the bivalves there was only $a$ significant difference between the mean $\delta^{15} \mathrm{~N}$ values of the shipworm and the Blue mussel.

\section{Discussion}

Several species of shipworms including Teredo navalis seem to be able to grow in the absence of food (apart from wood) as demonstrated under laboratory conditions (Gallager et al., 1981, Man and Gallager, 1985). The presence of phytoplankton supplement enhanced growth in the shipworm, Bankia gouldi, but was progressively less significant in the shipworms $T$. navalis and Lyrodus pedicellatus (Man and Gallager, 1985). Becker (1959, in Nair and Sarawathy) managed to rear $L$. pedicellatus through four generations in artificial sea water without any additional food. He was unsuccessful with $T$. navalis that failed to breed probably on account of inadequate nutrition, owing to the absence of protein rich plankton. Mann and Gallager (1985) observed well developed gonads with sperm and ova present for Bankia gouldi in the absence of planktonic food but did not mention this for $T$. navalis as gonad development was not part of their study. Turner (1966) suggested that the adults of some species require planktonic food during the breeding period, while others may be capable of surviving on plankton only as do many other bivalves.

The $\delta^{13} \mathrm{C}$ values of the shipworm $T$. navalis were on average $3.3 \%$ higher than that of the wood it lived in. This is far above the range of 0 to $1 \%$ if wood would have been the main source of carbon. The shipworm's $\delta^{13} \mathrm{C}$ values closely resembled the $\delta^{13} \mathrm{C}$ values of the Blue mussel and were higher than the $\delta^{13} \mathrm{C}$ values of the Pacific oyster. This means that not the wood it bores into but food obtained by filter feeding via the siphons was the main source of carbon, despite the presence of possible symbiotic cellulolytic nitrogen fixing bacteria in the gills of this species of shipworm. It further indicates that under natural conditions drilling in wood by the shipworm, T. navalis, is more important for shelter than nutrition.

The positive difference between the $\delta^{15} \mathrm{~N}$ of the bivalves compared with the $\delta^{15} \mathrm{~N}$ of wood was more than twice the $3.4 \pm 1.1 \%$ value for each consecutive trophic level through the food web (DeNiro and Epstein, 1978, Minagawa and Wada, 
1984, Wada et al., 1987), further the $\delta^{15} \mathrm{~N}$ of the shipworm was very close to the $\delta^{15} \mathrm{~N}$ of the Blue mussel and Pacific oyster. This excludes wood as the main source for nitrogen, and that food must have been acquired by filter feeding of seston. It would be very illogical that food present in the inhaled water would not be utilized as a carbon and nitrogen source.

This means that under natural conditions symbiosis between shipworm, $T$. navalis, and endosymbionts is not a case of mutualism but rather of commensalism from the latter.

\section{Acknowledgements}

We thank Marij Orbons for preparing the samples and Jelle Eygensteyn for measuring the stable isotopes.

\section{References}

Becker, G., 1959. Biological investigations on marine borers in Berlin-Dahlem. In Marine boring and fouling organisms. Ray, D.J. (ed.). University of Washington Press, Seattle, 62-76.

Betcher, M.A., Fung, J.M., Han, A.W., O'Connor, R., Seronay, R., Concepcion, G.P., Distel, D.L., Haygood, M.G., 2012. Microbial distribution and abundance in the digestive system of five Shipworm species (Bivalvia: Teredinidae). PLoS ONE, 7(9): e45309. doi:10.1371/journal.pone.0045309

DeNiro, M.J., Epstein, S., 1978. Influence of diet on the distribution of nitrogen isotopes in animals. Geochimica et Cosmochimica Acta, 42: 495-506.

Distel, D.L., DeLong, E. F., Waterbury, J.B., 1991. Phylogenetic characterization and in situ localization of the bacterial symbiont of shipworms (Teredinidae: Bivalvia) by using $16 \mathrm{~S}$ rRNA sequence analysis and oligodeoxynucleotide probe hybridization. Applied Environmental Microbiology, 57: 2376-2382.

Distel, D.L., Beaudoin, D.J., Morrill, W., 2002. Coexistence of multiple proteobacterial endosymbionts in the gills of the wood-boring Lyrodus pedicellatus (Bivalvia: Teredinidae). Applied Environmental Microbiology, 68: 6292-6299.

Distel, D.L., 2003. The biology of marine wood boring bivalves and their bacterial endosymbionts. In: Wood deterioration and preservation: Advances in our changing world. Goodell, B., Nicholas, D.D., Schulz T. (eds.). American Chemical Society, 253-271

Fry, B., Anderson, R.K., Entzeroth, L., Bird, J.L., Parker, P.L., $1984 .{ }^{13} \mathrm{C}$ enrichment and oceanic food web structure in the northwestern Gulf of Mexico. Contributions to Marine Science, 27: 49-63. 


\section{Chapter 4}

Gallager, S., Turner, R., Berg, C., 1981. Physiological aspects of wood consumption, growth, and reproduction in the shipworm Lyrodus pedicellatus Quatrefages (Bivalvia: Teredinidae). Journal of Experimental Marine Biology and Ecology, 52: 63-77.

Gu, B., Schelske, C.L., Hoyer, M.V., 1996. Stable isotopes of carbon and nitrogen as indicators of diet and trophic structure of the fish community in a shallow hypereutrophic lake. Journal of Fish Biology, 49: 1233-1243.

Jenner, H.A., Rajagopal, S., Van der Velde, G., Daud, M.S., 2003. Perforation of ABS pipes by boring bivalve Martesia striata: a case study. International Biodeterioration and Biodegradation, 52: 229-232.

Lechene, C., Luyten, Y., Mcmahon, G., Distel, D., 2007 Quantitative imaging of nitrogen fixation by individual bacteria within animal cells. Science, 317: 1563-1566. doi: PMID: 17872448.

Mann, R., Gallager, S.M., 1985. Growth, morphometry and biochemical composition of the wood boring molluscs Teredo navalis L., Bankia gouldi (Bartsch), and Nototeredo knoxi (Bartsch) (Bivalvia: Teredinidae). Journal of Experimental Marine Biology and Ecology, 85: 229-251.

Minagawa, M., Wada, E., 1984. Stepwise enrichment of ${ }^{15} \mathrm{~N}$ along food chains: further evidence and the relation between $\delta^{15} \mathrm{~N}$ and animal age. Geochimica et Cosmochimica Acta, 48: 1135-1140.

Nair, N.B., Saraswathy, M., 1971. The biology of wood-boring teredinid molluscs. Advances in Marine Biology, 9: 335-509.

Paalvast, P., Van der Velde, G., 2011. Distribution, settlement and growth of first year individuals of the shipworm Teredo navalis L. (Bivalvia: Teredinidae) in the Port of Rotterdam area, the Netherlands. International Biodeterioration and Biodegradation, 65: 379-388.

Pechenik, J.A., Perron, F.E., Turner, R.D., 1979. The role of phytoplankton in the diets of adult and larval shipworms, Lyrodus pedicellatus (Bivalvia: Teredinidae). Estuaries, 2: 58-60.

Popham, J.D., Dickson, M.R., 1973. Bacterial associations in the teredo Bankia australis (Lamellibranchia: Mollusca). Marine Biology, 19: 338-340.

Rau, G.H., Mearns, A.J., Young, D.R., Olson, R.J., Schäfer, H.A., Kaplan, I.R., 1983. Animal ${ }^{13} \mathrm{C} /{ }^{12} \mathrm{C}$ correlates with trophic level in pelagic food webs. Ecology, 64: 1314-1318.

Sipe, A.R., Wilbur, A. E., Cary, S.C., 2000. Bacterial symbiont transmission in the wood-boring shipworm Bankia setacea (Bivalvia: Teredinidae). Applied Environmental Microbiology, 66: 1685-1691.

Turner, R.D., 1966. A survey and illustrated catalogue of the Teredinidae (Mollusca: Bivalvia). Cambridge, Massachusetts: The Museum of Comparative Zoology, Harvard University. 
Vander Zanden, M.J., Cabana, G., Rasmussen, J.B., 1997. Comparing trophic position of freshwater fish calculated using stable nitrogen isotope ratios $\left(\delta^{15} \mathrm{~N}\right)$ and literature dietary data. Canadian Journal of Fisheries and Aquatic Sciences, 54: 1142-1158.

Vander Zanden, M.J., Rasmussen, J.B., 1999. Primary consumer $\delta^{13} \mathrm{C}$ and $\delta^{15} \mathrm{~N}$ and the trophic position of aquatic consumers. Ecology, 80: 1395-1404.

Wada, E., Terazaki, M., Kabaya, Y., Nemoto, T., $1987 .{ }^{15} \mathrm{~N}$ and ${ }^{13} \mathrm{C}$ abundances in the Antarctic Ocean with emphasis on the biogeochemical structure of the food web. Deep-Sea Research, 34: 829-841

Wada, A., Hattori, A., 1991. Nitrogen in the sea: Forms, Abundances and Rate Processes. Florida, CRC Press. 
